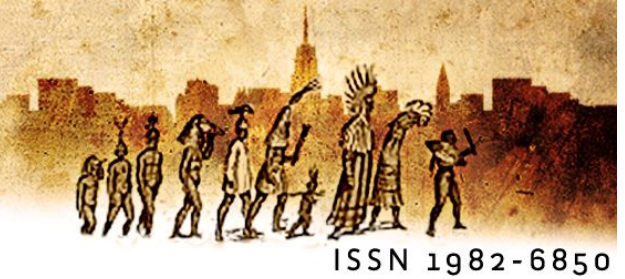

\title{
O Paganismo Essencial em Ricardo Reis
}

\author{
José Alexandre Ferreira Maia ${ }^{i}$
}

\section{Termo e Conceito de Paganismo}

Na atualidade, paganismo é um termo associado, de forma particular, a várias espécies de bruxarias, principalmente as que são derivadas de ritos remanescentes dos druidas; ou, de maneira geral, a qualquer rito não cristão. Nota-se, portanto, que o termo praticamente deixou de possuir o sentido que adquiriu com seu emprego primitivo observado principalmente no livro de Orósio dedicado a Santo Agostinho Historiarum Adversum Paganos Libri onde se lê:

Praeceperas mihi, uti aduersus vaniloquam pravitatem eorum, qui alieni a civitate Dei ex locorum agrestium conpitis et pagis pagani vocantur sive gentiles quia terrena sapiunt, qui cum futura non quaerant, praeterita autem aut obliviscantur aut nesciant, praesentia tamen tempora veluti malis extra solitum infestatissima ob hoc solum quod creditur Christus et colitur Deus, idola autem minus coluntur, infamant. ${ }^{1}$

\footnotetext{
1 "Pregas a mim contra a louca depravação daqueles que fora da cidade de Deus, nas encruzilhadas e nos povoados (pagis), são chamados pagãos (pagani) ou gentis porque saboreiam as coisas terrenas, e como não se preocupam com o futuro, esquecem o passado e desconhecem o presente, os difamam como se infestado de forma incomum pelos males, contra este único tempo em que Cristo é acreditado, Deus é louvado e os ídolos são cada vez menos cultivados". (OROSIUS, Paulus. Historiarum Adversum Paganos Pauli Orosii Liber Primus $(1,9)$, tradução minha)

Disponivel em: http://thelatinlibrary.com/orosius/orosius1.shtml Acesso em: 13/08/2015.
} 
Os pagãos, se pudermos inferir a partir de Orósio, foram aqueles cidadãos do Império Romano que não acompanharam as transformações históricas que levaram o Cristianismo a se alojar e a se desenvolver no centro de decisões do estado imperial: os centros urbanos. Os pagãos foram aqueles que mantiveram crenças nos deuses e nos ritos; eram a escória da decadente cultura romana. Espalhavam-se pelos campos às ocultas, muitas vezes até se embrenhavam nas florestas, não possuíam educação, exceto as lembranças dos seus ritos. A Cidade de Deus, a cidade cristã, ainda em construção, mas que em grande parte do império já havia substituído as cidades politeístas, com grande parte de sua estrutura já consolidada, lançou seu domínio sobre os meios físicos e institucionais urbanos, todavia o império agonizava moralmente e sofria com as invasões bárbaras.

A Antiguidade como uma unidade histórica está compreendida em um contexto universal complexo, mas acreditamos ser possível identificar um processo evolutivo, em cujo seio estão presentes as tensões culturais e sociais que irão ocasionar a manutenção daquela ordem clássica alcançada pelo intelecto grego, desde Homero. Esta cultura antiga, a cultura homérico-platônica, designada normalmente como clássica, passou a ser designada também como pagã, pelos cristãos. Mas isto foi resultado de um deslocamento semântico, ou até mesmo de um apelo depreciativo em relação aos valores clássicos. Entretanto, hoje, o termo paganismo aparece normalmente para designar também a cultura clássica: seu politeísmo, sua sensualidade, seus ideais olímpicos e tumulares. Grandes foram os momentos de esplendor desta cultura, principalmente aqueles protagonizados pelos próprios gregos, nos séculos: VI, V e IV. Depois sucedendo a isto vieram: o esplendor de cidades helenísticas como Alexandria, Éfeso, Pérgamo, Antioquia; o domínio romano; e por fim o Cristianismo que também contribuiu para tornar a cultura clássica algo preponderante e uniforme no mundo antigo.

Mas foi Horácio, um romano nascido em Venúsia, no século I a.C quem terá enunciado de modo mais preciso e clarividente os valores e os ideais desta cultura clássica completamente híbrida, mas helenizada, em plena era de sua decadência, quando é a mão romana que está sobre o mundo grego, dominando o Mediterrâneo e o Oriente, expandindo-se para o Ocidente na Europa e na África: "a vasta região que Roma havia conquistado não era toda barbaresca, uma grande área abrangia os povos de cultura 
helenística, refinados de língua, literatura e ciência, maduros em filosofia e belas artes. Esta riqueza espiritual estava agora fluindo para Roma" (DURANT, 1987, p.285).

Horácio ao viver este contexto delineou a sobriedade satírica dos romanos, reconheceu o seu papel na retomada dos valores helênicos e itálicos e com grande êxito enunciou, assim como fizeram os mais famosos poetas líricos gregos e alexandrinos, o espírito que deu vida àquela cultura. O helenismo fluía em Roma e já se consolidara em vários autores latinos, como Cícero, Catulo, Lucrécio, mas, no período em que a paz se estabelece, o gênio romano desperta para forjar um liame cultural e um sincretismo religioso jamais concebidos entre Roma e Grécia em suas raízes míticas e históricas. A poesia voltava a ter a função social primordial. O Auditorium, encontrado em terras de Mecenas, demonstra esta importante função social. O refinado evergeta proporcionaria, sem dúvida, encontros monumentais entre Virgílio e Horácio, para a récita e a leitura de seus versos.

A Grécia renascia no coração de Roma, e o seu melhor pintor lírico não poupou a tinta para desenhar o quadro das sensações geradas pelo culto aos deuses e às suas cortes divinas. Eis o paganismo essencial, eis onde o culto e a tradição reverberam em ricas imagens da doçura, da simplicidade, da despreocupação, do prazer sereno de estar vivo, do saborear o vinho, da contemplação da dança harmoniosa da natureza primaveril, da beleza ardente da juventude, da sedução feminina, do tempo implacável, da ação inevitável da morte e perenidade da poesia.

É este conjunto de imagens que forma o quadro do paganismo essencial, onde o homem livre, no centro de uma sociedade escravocrata, pode escolher entre uma vida de preocupações mundanas e uma vida enriquecida por momentos agradáveis que não deixam de ser mundanos, mas unido ao sagrado e às tradições mítico-poéticas, é de onde se deve tirar proveito cultural no fruir da vida. Um mundo de sensações onde a doçura lírica é o meio termo do ideal clássico.

Modelo mais bem-acabado dos ideais gregos, o paganismo de Horácio inspirou o movimento conhecido como Neopaganismo Português. Ricardo Reis foi o heterônimo que Pessoa usou para enunciar suas ideias acerca deste movimento criado para corrigir os efeitos danosos da cultura moderna. Segundo Leyla Perrone-Moisés, 
Reis foi o principal teorizador do Neopaganismo Português, movimento que tinha um ambicioso objetivo cultural: corrigir os erros da civilização cristã, responsável pela decadência do Ocidente, recuperar a clarividência e a saúde mental das civilizações pagãs Grécia e Roma. (In: PESSOA, 2000, [orelha])

Ricardo Reis, nascido dentro da alma de Pessoa, como ele mesmo chega a escrever, foi trazido à vida por uma espécie de processo de reencarnação ficcional, um processo através do qual chegou intacto ao século XX. O gênio de Pessoa já havia dado provas de que a criação de heterônimos se tornaria uma prática bem-sucedida. O paganismo de Ricardo Reis é uma criação tão fascinante quanto sua própria existência. Pessoa trabalhava em suas invenções heteronímicas com o mesmo cuidado com que um grande romancista trabalha seus personagens. Ele reencarnou um pagão para teorizar acerca do paganismo, pois ao conceber uma teoria neoclássica achou interessante desenvolvê-la "segundo princípios que não adotava nem aceitava" (PERRONE-MOISÉS In: PESSOA, 2000, [orelha]).

Pessoa reelaborou o paganismo horaciano e o fez se inscrever como um repúdio satírico ao artificialismo das vanguardas modernistas, mas diferentemente destas, devido a sua consistência enunciativa, galgou uma alta escala poética. O grande feito de Pessoa/Reis foi desenvolver uma poética plasmada nos gêneros românico-helenísticos, adotando a forma primordial das odes e sua complexidade métrica, assim como Horácio havia feito com os metros gregos e helenísticos de Arquíloco, Alceu, Safo e Asclepíades. Com isto fez surgir uma língua portuguesa revelada em seu âmago latino, em seu forte laço pagão e em sua maleável adaptação ao ambiente mediterrâneo românico.

Este paganismo nascido no seio da modernidade - em que o próprio Cristo é apenas mais um deus que indiferente à vida dos homens acolhe suas homenagens e aproveita sua ascensão ao panteão - é único e guarda profundas diferenças com outros reconhecidos neoclassicismos, tais como o de Hölderlin, de Keats, ou de Edgar Allan Poe.

O projeto de Ricardo Reis é fundir sua língua aos ideais pagãos e assentá-los em sua poética: seguro assento na coluna firme.

É assim que sua poética pagã se torna originalíssima e conquista um êxito estéticoideológico sobre a esterilidade da imaginação da decadente sociedade moderna. Sua aurea mediocritas tal qual a de Horácio é a grande saída para os excessos e exageros da arte moderna, tanto quanto para sua falta de brilho e grandiloquência. 
Horácio terá sido o último grande autor a configurar com refinado senso poético os valores essenciais do paganismo. Em outros autores nota-se a decadência em face do afrouxamento moral e da depravação. A flagrante decadência do mundo pagão é perceptível principalmente na evolução do gênero satírico de Marcial e Juvenal, bem como na ascensão de desajeitado retoricismo que acompanhou a ruína da literatura pagã e, como um câncer, deteriorou seu espírito. Os gêneros literários mais elevados da tradição helênica darão lugar a gêneros periféricos como o romance grego, de cunho erótico, e o romance latino, de caráter satírico. E o gosto por espetáculos violentos substituirá o gosto por espetáculos refinados e elegantes comumente associados aos gêneros poéticos gregos, além disso, neste contexto, haverá, como já vimos, uma preocupação alienada pelo aprendizado retórico.

Por séculos, depois da queda do Império Romano do Ocidente, a elegante cultura clássica inspirou momentos de esplendor nos principais centros de irradiação e recepção da Cristandade. O renascimento na corte de Carlos Magno protagonizado por Alcuíno e seus monges copistas, no século IX. No século XIV e seguintes, Dante, Bocaccio, Petrarca deram impulso para o mais fecundo renascimento das artes gregas. No século XVIII, surge o neoclassicismo iluminista que se estende ao romantismo e ao racionalismo do século XIX e todos esses movimentos terão como inspiração a cultura pagã. Todavia todos se relacionam de algum modo ao Cristianismo, apenas em Fernando Pessoa e seu heterônimo é perceptível a realização de um paganismo essencial, sem a contaminação medieval ou moderna do Cristianismo ou do Racionalismo Ocidental que nasceu de sua ética e de sua estética. Pois é exatamente através desse paganismo elaborado poeticamente por Pessoa, que percebemos um renascimento inédito: os deuses estão vivos e é como se Júpiter nunca tivesse sido destronado pela Santíssima Trindade e assim experimentamos no apogeu desta sociedade tecnológica uma sensação que só a poesia e a força criativa de um gênio poético como o de Pessoa poderiam promover.

\section{Os Esquemas}

Ricardo Reis/Fernando Pessoa enuncia, em português, versos e canções trazidas do seio do mundo pagão como se acompanhadas pelas cordas do barbyton e moldadas à 
sintaxe melódica do latim horaciano. Tal proeza funcionou, em princípio, como manifesto do Neopaganismo Português, mas se transformou em um monumento da criação poética, que mesmo erguido em tempos modernos, encontra-se encoberto pela pátina espraiada sobre o bronze dos versos. Assim como escreveu Horácio: lexegi monumentum aere perennius/ regalique situ pyramidum altius/, no mesmo tom escreveu Ricardo Reis: /Assim na placa o eterno instante grava/Seu ser durando nela/.

Para elucidarmos este paganismo inédito, mal auferido e mal analisado, comecemos a colocá-lo dentro de uma perspectiva histórico-semiológica na qual possamos vislumbrar o panorama contextual estético e ideológico do mundo essencialmente pagão. Iniciemos por compreender que a inserção social e cultural da poesia grega no mundo pagão através da diversidade de suas formas transformou-a no seu principal elemento representativo. $\mathrm{Na}$ verdade, no mundo helênico, a poesia foi um gênero cultural fundador que impulsionou a invenção e o aprimoramento de vários outros gêneros. Neste contexto, as artes verbais permeiam todos os fatos e acontecimentos, ritos e cerimoniais. Como bem coloca JAEGER (2001, p. 70):

a poesia mélica nasce das canções populares (...), o iambo, dos cantos das festas dionisíacas, os epitalâmios, das cerimônias populares das bodas; as comédias, dos komos; as tragédias, dos ditirambos (...) a didática e a elegia seguem os passos da épica e as formas da prosa literária - a História e a Filosofia - nasceram e se desenvolveram diretamente da discussão relativas à visão do mundo contida na epopeia, a epopeia é a raiz de toda a formação superior na Grécia

Nesta complexa estrutura de gêneros culturais a poesia é, principalmente no que diz respeito à epopeia homérica, desencadeadora de outros gêneros. Mas na idade Clássica, do século VI ao IV a. C, encontramos um contexto no qual, competindo com a poesia, havia uma verdadeira profusão de gêneros prosaicos e teóricos, de foco realista (filosofia, história, retórica, erudição em gramática, geografia, medicina, matemática, astronomia), além dos gêneros não verbais: escultura, pintura, arquitetura. Este contexto competitivo assinala a dinâmica social dos gêneros culturais e revela a complexa realidade das tensões estéticas e ideológicas presentes no fracasso e no êxito desses gêneros e, por conseguinte, da cultura a 
eles sistematicamente associada. Obviamente a cultura helênica, transformada em helenística, românica e cristã, não era assimilada em sua totalidade nesses contextos legatários. Os gêneros culturais helênicos eram absorvidos de acordo com as demandas estético-ideológicas de cada contexto, onde sofriam profundas transformações ou adaptações.

De uma maneira geral, a sociedade helenística escamoteou a epopeia e a tragédia, mas cultivou a lírica monódica e a comédia. Com a ascensão de Roma desencadeou-se uma espécie de renascimento de todos os gêneros helênicos, contudo fortemente marcados pelo hibridismo frívolo do modelo helenístico. A helenização de Roma encontrou seu apogeu na Idade de Ouro, mas com os cristãos, o modelo helenístico-românico fundiu-se ao modelo judaico, todavia nestes três contextos a natureza original dos gêneros era preservada sob o aspecto da imitação tosca, ou, no máximo, da imitação perfeita do modelo. Até mesmo os modelos cristãos passavam por adotar esquemas gregos, haja vista seus primeiros escritos em língua grega.

Roma estava no caminho da evolução da cultura pagã. Assimilou seus gêneros de tal modo que se constituiu como o centro de esplendor desta cultura. No seio desta prosperidade está Horácio, cujo talento seria reconhecido e celebrado por todo e qualquer classicismo. Isto se deve não só ao talento, mas ao poder de representação de sua obra lírica, ao êxito por ela atingido, tanto na forma, quanto no seu elevado significado. Como ressalta DURANT (1954, p. 302) sobre Horácio,

e como houvesse saboreado os vívidos metros de Safo, Alceu, Arquíloco e Anacreonte, teve a ideia de transpor esses metros "sáficos" e "alcaicos" esses hendecassílabos e jâmbicos, para a lírica latina, a fim de exprimir-se sobre o amor e o vinho, a religião e o estado, a vida e a morte por meio de estâncias frescas e novas compactamente epigramáticas, melódicas e engenhosas.

Ricardo Reis faria jus a todos os elogios atribuídos a Horácio. Sua criação prova o estrondoso gênio de Fernando Pessoa, que, afetado culturalmente pelo modernismo, pelo revolucionário rompimento de todos os laços culturais do passado europeu, concebeu uma literatura puramente alheia a ele próprio através dos heterônimos. A síntese poética de Pessoa envolve fingimento e criação. Fingimento porque a realidade é puro jogo sensorial 
iludindo o intelecto rudimentar do ser humano; criação, porque a poesia é criação verbal em profusão ordenada. Seu paganismo fingido enuncia o absurdo de estar e não estar no mundo, de ser um e não ser único.

Assim como cada heterônimo de Fernando Pessoa, Ricardo Reis enuncia demarcando sua identidade discursiva. Pois há para cada um deles, uma biografia fora dos gêneros literários, mas inserida na rede de enunciações como se fossem discursos proferidos por autores reais. O processo é óbvio, mas extremamente difícil de compreender a não ser que possamos discernir pragmaticamente. Ricardo Reis é um autor cuja "biografia" demarca e assinala uma paratopia evidente (CHARAUDEAU \& MAIGUENEAU, 2004, p. 368), pois interage discursivamente com a sociedade. Incorpora o paganismo para enunciar como Horácio reelaborando os seus esquemas e não só isto, trazendo-os frescos da Antiguidade a um contexto Moderno.

\section{Referências}

CHARAUDEAU, P. ; MAINGUENEAU, D. O Contexto da Obra Literária; trad. Fabiana Komesu. São Paulo: Martins Fontes, 1995.

DURANT, Will. História da Civilização: César e Cristo; trad. Monteiro Lobato - 3. Parte; Tomo I - São Paulo: Companhia Editora Nacional, 1987.

JAEGER, Werner. Paidéia. São Paulo: Martins Fontes, 2001.

OROSIUS, Paulus. Historiarum Adversum Paganos Pauli Orosii Liber Primus $(1,9)$

Disponível em: http://thelatinlibrary.com/orosius/orosius1.shtml Acesso em: 13/08/2015.

PERRONE-MOISÉS, Leyla. [Orelha] In: PESSOA, Fernando. Poesia: Ricardo Reis. São Paulo: Companhia das Letras, 2000.

PESSOA, Fernando. Poesia: Ricardo Reis. São Paulo: Companhia das Letras, 2000. 
' José Alexandre Ferreira Maia é professor de Língua e Literatura Latinas do Departamento de Letras da Universidade Federal de Pernambuco, onde já exerceu cargos de Coordenador de Graduação (1996/1997) e Chefe de Departamento (2008/2010). Mestre e Doutor em Teoria Literária na mesma Universidade, com estágio de doutorado financiado pela CAPES na Universidade de Évora, Portugal. Criou e coordenou o Seminário de Línguas e Literaturas Clássicas 2008, 2009, 2010, 2012 e 2013. Sua última publicação na Eutomia foi em 2009 com o artigo: A Busca do Tempo no Tempo da Busca em Carlos Pena Filho. 